\title{
Domestic wells have high probability of pumping septic tank leachate
}

\author{
J. E. Bremer ${ }^{1, *}$ and T. Harter ${ }^{1}$ \\ ${ }^{1}$ Department of Land, Air, and Water Resources, University of California, Davis, CA 95616-8629, USA \\ * now at: Institute of Photogrammetry and Remote Sensing, Karlsruhe Institute of Technology (KIT), Kaiserstr. 12, \\ 76131 Karlsruhe, Germany
}

Correspondence to: T. Harter (thharter@ucdavis.edu)

Received: 16 May 2011 - Published in Hydrol. Earth Syst. Sci. Discuss.: 15 June 2011

Revised: 14 June 2012 - Accepted: 28 June 2012 - Published: 3 August 2012

\begin{abstract}
Onsite wastewater treatment systems are common in rural and semi-rural areas around the world; in the US, about $25-30 \%$ of households are served by a septic (onsite) wastewater treatment system, and many property owners also operate their own domestic well nearby. Site-specific conditions and local groundwater flow are often ignored when installing septic systems and wells. In areas with small lots (thus high spatial septic system densities), shallow domestic wells are prone to contamination by septic system leachate. Mass balance approaches have been used to determine a maximum septic system density that would prevent contamination of groundwater resources. In this study, a source area model based on detailed groundwater flow and transport modeling is applied for a stochastic analysis of domestic well contamination by septic leachate. Specifically, we determine the probability that a source area overlaps with a septic system drainfield as a function of aquifer properties, septic system density and drainfield size. We show that high spatial septic system density poses a high probability of pumping septic system leachate. The hydraulic conductivity of the aquifer has a strong influence on the intersection probability. We find that mass balance calculations applied on a regional scale underestimate the contamination risk of individual drinking water wells by septic systems. This is particularly relevant for contaminants released at high concentrations, for substances that experience limited attenuation, and those that are harmful even at low concentrations (e.g., pathogens).
\end{abstract}

\section{Introduction}

In rural, semi-rural, and many suburban areas, septic systems (onsite wastewater treatment systems, OWTS) are the primary method for wastewater disposal. In the US, about one in four households operates a septic system and almost onethird of new homes are constructed with an OWTS as their wastewater disposal system (US EPA, 2003a; US DC, 2008). Septic systems traditionally include a septic tank linked to a drainfield, through which minimally treated wastewater is leached into groundwater (Kaplan, 1991; Woodson, 2003). Surveys indicate that at least $20 \%$ of these systems are malfunctioning; over half of all US septic systems are over 30-yr old (US EPA, 2005). Old and improperly maintained systems are prone to failure and provide inadequate conditions for the effluent treatment processes including physical filtration, surface adsorption, sedimentation, and inactivation of the contaminants in the soil (Canter, 1997; Charles et al., 2005). Leachate from septic systems has been identified as a major potential source of groundwater contamination with nitrate, pharmaceutically active compounds (PhACs), endocrine active substances (EAS), other household chemicals, as well as pathogens such as bacteria, viruses, helminths, and protozoa (Perkins, 1984; US EPA, 1998, 2002a; Gerba and James, 2005; Carroll et al., 2006; Fong et al., 2007; Stanford et al., 2010).

Commonly, residences that are using septic systems also provide their own water from a domestic well located on the same property ("lot") as the septic system, thus leading to a potential risk of drinking water contamination (DeSimone, 2009; Katz et al., 2011). Water wells in close proximity to 
septic systems on soils with a very high sand fraction, shallow unconfined aquifers, in karst terrain, or on fractured crystalline rocks are especially vulnerable to contamination by pathogens (Scandura and Sobsey, 1997; DeBorde et al., 1998; Frazier et al., 2002; Miller and Ortiz, 2007; Harden et al., 2008; Humphrey Jr. et al., 2010). Yates et al. (1985) and Yates (1991) pointed out that the most common cause of waterborne disease outbreaks in the US is contamination of well water by septic systems. Over 168000 viral illnesses and 34000 bacterial illnesses occur each year due to consumption of improperly treated groundwater used for drinking water purposes, according to US Environmental Protection Agency estimates (US EPA, 2003a).

States and local governments increasingly regulate the design, installation, and maintenance of septic systems. Partially with nearby septic systems in mind, many local and state regulations also address the design of domestic wells including minimum screen depth and surface seal depth (Woodson, 2003; US EPA, 2002c). Most regulatory development is recent and did not apply at the time most existing septic systems and domestic wells were constructed (e.g., SWRCB, 2012; US EPA, 2005). Moreover, regulations are typically developed based on very simple perceptions of groundwater flow; site-specific flow conditions are not accounted for (US EPA, 2002b). As Borchardt et al. (2011) demonstrated in a case study, poor understanding of groundwater flow can lead to drinking water contamination, even if newly established septic systems are strictly built according to regulations. Few quantitative tools are available that would allow regulators, planners, or homeowners to assess the possibility of domestic wells pumping septic leachate-impacted groundwater (Wilcox et al., 2010).

One approach to prevent excessive aquifer contamination is to determine a minimum required lot size or a critical maximum septic system density, which is the maximum number of septic systems per area that would not lead to overstraining the soil's purifying and the aquifer's dilution capacity. Many studies demonstrated significant correlations of septic system density to contaminant concentrations and disease outbreaks (Schmidt, 1972; Pitt, 1974, 1975; Konikow et al., 1978; Katz et al., 1980; Duda and Cromartie, 1982; Bicki et al., 1985; Yates, 1985, 1991; Hantzsche and Finnemore, 1992; Nizeyimana et al., 1996; Canter, 1997; Whitehead and Geary, 2000; Borchardt et al., 2011; Standley et al., 2008). In US EPA (1977), the agency specified a septic system density exceeding 40 systems per square mile (1 system per 16 acres) as at risk of groundwater contamination and considered septic system density to be the most important control of contamination risk from septic systems. Dawes and Goonetilleke (2003), Miller (1972), Bauman and Schäfer (1985) and Wright (1975) came to similar conclusions after having measured and studied excessive nitrate levels in areas with high septic system density. In comparison, rural areas of the central and western US are typically zoned to a minimum lot size of $0.5-1$ acre $\left(\sim 2000-4000 \mathrm{~m}^{2}\right)$ in agricultural-residential areas and a lot size of 20 acres $\left(\sim 81000 \mathrm{~m}^{2}\right)$ in exclusively agricultural areas.

Several approaches have been used to determine a minimum lot size or maximum septic system density, respectively:

- empirical and statistical field studies to determine the necessary minimum lot size that has historically been protective of groundwater quality in specific regions,

- mass balance computations based on the amount of groundwater needed to sufficiently dilute typical septic leachate loading to levels that meet drinking water requirements (e.g., for nitrate),

- site-specific numerical transport modeling studies that allow for a fully two- or three-dimensional evaluation of subsurface flow and transport conditions, and

- field-site evaluation and measurements.

Trela and Douglas (1978) and Brown (1980) established dilution models to determine a maximum septic system density for sandy soils. The flow and transport model of Konikow et al. (1978) was applied to study effects of septic system densities. Lowe et al. (2003), Bishop et al. (2007) and Lowe et al. (2011) used a groundwater flow model coupled with a mass balance approach to evaluate the risk associated with septic system densities. However, while an overall mass balance may show limited impact of septic tank leachate on contaminant concentrations, individual wells may be significantly affected by septic effluent contaminants (Kaplan, 1991).

To prevent contamination, regulators also use minimum requirements for horizontal setback distances between drinking water wells and drainfields, and minimum vertical separation distances between drainfields and the seasonally highest groundwater table. These setback distances are intended to ensure a minimum residence time for septic tank leachate in the subsurface that allows decay, absorption and dilution of chemical and microbiological contaminants. A common setback distance, for example, used by local regulators in

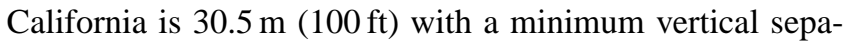
ration distance of 1.5-3 $\mathrm{m}(5-10 \mathrm{ft})$. However, the prescribed distances may fail to protect water quality in two ways: The physical assumptions used to estimate the residence time may be incorrect, leading to subsurface residence times that are too short to allow contaminant decay; or the prescribed residence times themselves may be too short to allow sufficient remediation of septic tank leachate.

In the first case, setback distances are regularly prescribed based on a set of assumed aquifer characteristics: flow rates, conductivities, and flow directions. Violation of these assumptions can lead to increased pollution risk relative to the regulatory assumptions (Yates and Yates, 1989; Postma et al., 1992; DeBorde et al., 1998; Corbett et al., 2002; Lipp et al., 2001). As would be anticipated intuitively, horizontal and 
vertical set back distances required to meet health standards are most sensitive to horizontal and vertical hydraulic conductivity, and the local hydraulic gradient (Harmsen et al., $1991 b, a)$. Neglecting the local groundwater flow direction can increase the pollution risk relative to the regulatory assumptions (Kerfoot, 1987). Not only aquifer properties and groundwater flow directions influence the pollution risk of domestic wells, but also the gravel pack around well screens and casings: When considering the typical design of most domestic drinking water wells, Horn and Harter (2009) found that the gravel pack might serve as a "short circuit" for contaminants, and typical set back distances of $30.5 \mathrm{~m}$ may be inadequate to prevent well contamination from nearby septic systems, especially in less permeable aquifers.

In the second case, prescribed subsurface residence times may fail since setback distances and maximum septic system densities (see above) have primarily been estimated using coliform bacteria or nitrate as representative contaminants. These studies generally did not consider other potential contaminants of septic system leachate with differing behavior in the aquifer. Some contaminants of particular concern (e.g., organic micro-pollutants and viruses) are among the most mobile contaminants and are harmful at concentrations that are orders of magnitude lower than in septic leachate (Gerba, 1984; Heberer, 2002; Osenbrück et al., 2007; Gray, 2008; Stanford et al., 2010). Hence, it is important to know if a direct intersection of the source area of a private drinking water well and a leachfield (also called drainfield) of a septic system exists. Not only the well owner's septic system is of concern but also neighboring septic systems are to be taken into account.

A rigorous, physically based, yet general, assessment of the impact from septic leachate to domestic wells is needed to evaluate contamination risk to domestic wells. Basin-wide, regional (e.g., county), or sub-regional assessments, however, typically face either a lack of detailed data or very large spatial complexity in the data representing the location of large numbers of septic leach fields and domestic or other production wells. Here, we adopt a simplified, but general probabilistic analysis that allows for a physically based assessment of septic leach field impact to domestic wells, yet is sufficiently general to be applicable to a wide range of conditions.

In this study, we develop a spatial stochastic analysis to evaluate, across a wide range of representative aquifer and land-use conditions, the probability that the source area of a domestic well intersects one or several septic drainfields. We derive intersection probabilities as a function of aquifer hydraulic conductivity, hydraulic conductivity anisotropy ratio, and septic system density in rural and semi-rural areas overlying unconsolidated sedimentary (e.g., alluvial) aquifers. Sedimentary aquifers are amongst the most productive aquifers and are a major groundwater resource worldwide (BGR, 2012). But they are also particularly vulnerable to contamination, and remediation is often difficult to perform (Harter et al., 2012).

Our analysis is based on a two-step approach: first, we develop a domestic well source area model that is derived from fully three-dimensional flow simulations around a typical domestic well to delineate its source area. We consider a typical domestic well design that also accounts for the effects of the well gravel pack, a potentially significant Achilles heel to the protective integrity of a well. The source area of a well is defined as the area of groundwater recharge that contributes to the well discharge. The simulated geometric shape of the source area is parametrized as a function of aquifer hydraulic conductivity (including anisotropy) and gravel pack hydraulic conductivity (Horn and Harter, 2009). In this paper, we apply the source area model to a stochastic analysis of the intersection of well source areas with septic drainfields, based on a numerical stochastic analysis of possible spatial configurations of the source area relative to septic drainfield locations.

We briefly summarize the conceptual approach taken to develop the source area model for a domestic well (Horn and Harter, 2009). We then describe in detail the methodology for the stochastic analysis and a wide range of typical aquifer conditions and land-use configurations to which it is applied. We compare results to mass balance-based septic system pollution risk estimates and discuss the broader implications of the results to understanding of potential septic system pollution of domestic drinking water.

\section{Source area model}

Domestic well source areas are obtained using a highly resolved three-dimensional numerical groundwater flow and particle tracking model, as described in detail by Horn and Harter (2009). Briefly, we assume that domestic wells tap into the shallower zone of a large regional groundwater system that is characterized by a regionally uniform horizontal gradient, over which we superimpose a vertical gradient that results from uniform recharge across the entire aquifer surface and distributed pumping in agricultural irrigation wells and in larger urban wells; these large production wells are typically completed in deeper production aquifer zones, below the domestic well pumping zone. The numerical model is a three-dimensional cuboid domain (Fig. 1) that encompasses the entire source area of the well. Constant head boundary conditions are prescribed at the lateral inflow (upgradient) and outflow (downgradient) boundaries of the simulation domain; constant recharge is prescribed at the top boundary. Constant discharge representing deep production well pumping is prescribed at the lower simulation boundary, and no flow is prescribed on the remaining two lateral boundaries of the cuboid domain. The domestic well screen is completed from $48 \mathrm{~m}$ to $56 \mathrm{~m}$ below the water table. The screen is embedded into a gravel pack that extends upward 


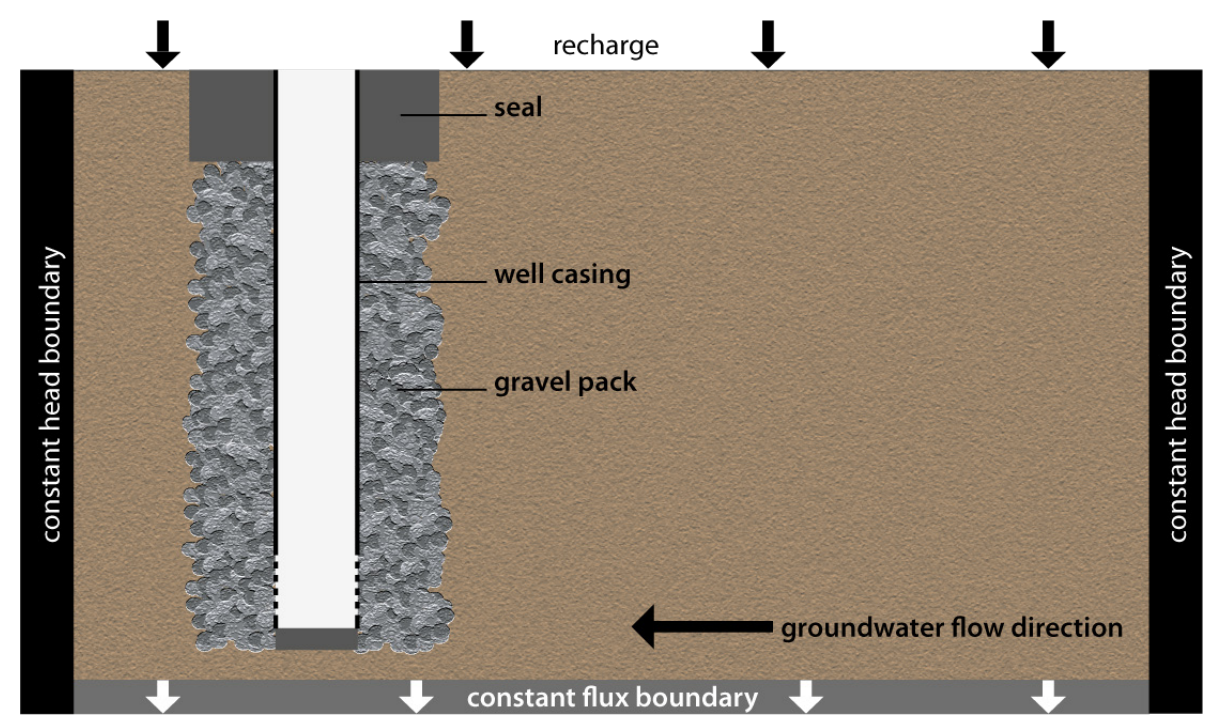

Fig. 1. Conceptual cross section of the 3-D groundwater model used to determine the size of the source area and its distance to the well (Horn and Harter, 2009). The gravel pack surrounding the well casing, the well screen, and the sealing below the surface are explicitly taken into account in the model set-up.

to $18 \mathrm{~m}$ below the water table (Fig. 1). These domestic well design values are representative for many domestic wells in alluvial aquifers. The specific depths correspond to the average screen depth obtained from over 3500 domestic well logs in the Central Valley, California (Burow et al., 2004).

To obtain the source area, we assume steady-state flow with an average areal recharge (from precipitation, irrigation, lawn irrigation, septic system drainfield) of $0.669 \mathrm{~m} \mathrm{yr}^{-1}$ and a pumping rate of $1234 \mathrm{~m}^{3} \mathrm{yr}^{-1}$. For these representative conditions, Horn and Harter (2009) numerically delineated the source area of domestic wells for a range of horizontal and vertical aquifer hydraulic conductivities, $K_{\mathrm{h}}$ and $K_{\mathrm{v}}$, and for a range of gravel pack hydraulic conductivities, $K_{\mathrm{g}}$. They used a finite difference solution of the steady state groundwater flow equation and used backward streamline tracking from the well to delineate detailed source area configurations.

Due to the relatively low pumping rate in the domestic wells, the source area typically extends in an elongated elliptical shape along the main, regional flow direction of the aquifer, upgradient of the well location. Horn and Harter (2009) showed that the gravel pack surrounding the well casing has a significant influence on the source area of a well and that the gravel pack extends the source area well-wards in a narrow elliptical band off the main elliptical source area. Horn and Harter (2009) modeled the simulated shapes of source areas using two mutually attached rectangles: one for the main source area, and one for the well-ward extended source area due to the gravel pack (Fig. 2). The simplified geometric source area representation is parametrized via the length and width of these two rectangles. A source area model was obtained by mapping the source area parameters as a function of aquifer hydraulic conductivity and anisotropy ratio, and as a function of the gravel pack hydraulic conductivity (Horn and Harter, 2009).

\section{Source area intersection with septic drainfields}

Whether or not the source area of a domestic well includes portions of a septic drainfield depends on aquifer properties, well properties, aquifer heterogeneity, the patterns of local groundwater flow, and the location of the well relative to the location of nearby septic drainfields. Without intensive site analysis, this information is generally not available with any high degree of certainty. Aquifer properties vary widely but can be estimated from geologic and well drilling information (Burow et al., 2004). Subsurface heterogeneity is difficult to assess and typically leads to increased dispersion ("macrodispersion"). Macro-dispersion increases the source area of a well (Kunstmann and Kastens, 2006). Regional groundwater flow direction can typically be retrieved from regional water level contour maps generated by state or federal agencies. However, the distance from a domestic well to its source area is often on the order of a few tens to a few hundreds of meters. At that scale, groundwater flow directions may be highly variable due to the influence of nearby large production wells used for irrigation or municipal water supply, due to the influence of local topography and hydrogeology (including large scale heterogeneity), and due to the local influence of nearby streams. In addition, the location of septic drainfields is often unmapped or entirely unknown. For a regional or general assessment, it is therefore difficult to determine the exact configuration of the flow field near a domestic well and whether or not the well source area intercepts a septic drainfield. 


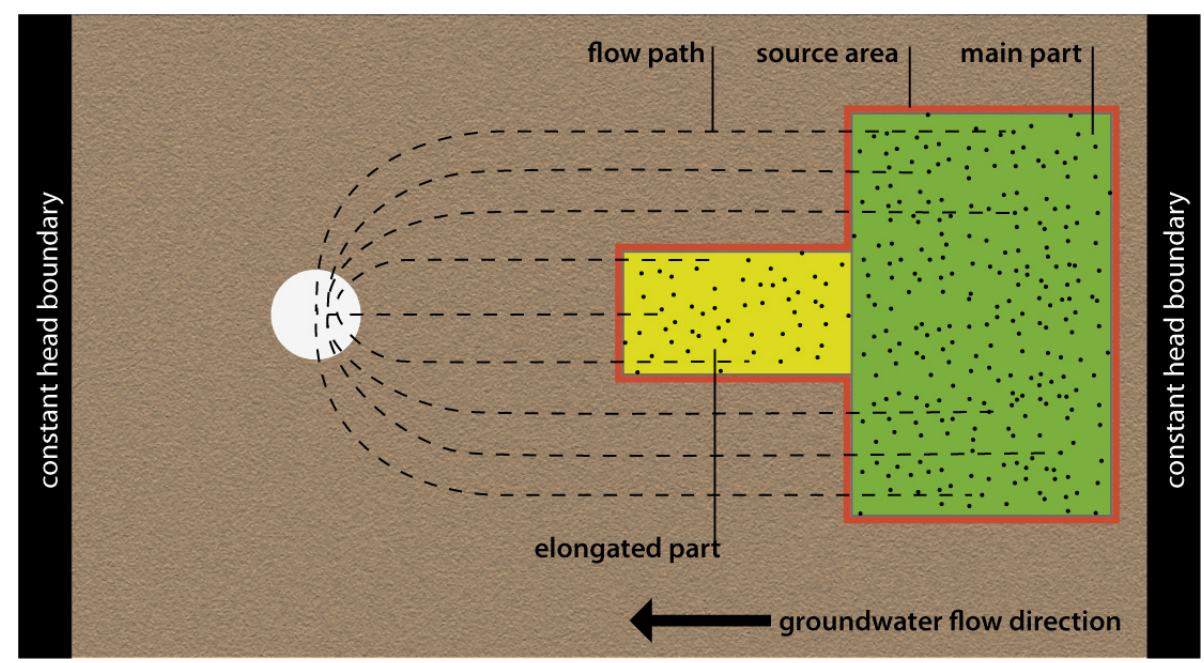

Fig. 2. Schematic representation of the conceptual framework to numerically determine the source area, plan view (compare to Fig. 1): The recharge location of particles (black dots) entering the well is determined by backward-tracking along the flow paths from the well to the water table (recharge) surface (Horn and Harter, 2009). To geometrically describe the source area, the two distinguishable particle clusters are enclosed by two rectangles. This leads to a source area (orange) consisting of a main part (green) with a narrower elongated part (yellow) extending towards the well. Based on the 3-D simulation results, the geometric shapes are parameterized as a function of aquifer and gravel pack hydraulic conductivities (Horn and Harter, 2009).

Lacking detailed information on the local flow field, we use a probabilistic approach. We make the following simplifying assumptions about aquifer properties, well locations, and septic drainfield locations to develop a tractable conceptual problem:

- The aquifer is considered to be homogeneous with uniform flow direction in the vicinity of the domestic well.

- The groundwater flow direction in the vicinity of the domestic well is unknown and is assumed to be in any direction with equal probability.

- The effects of dispersion on the source area of a well are neglected.

- Property lots are assumed to be quadratic in shape, uniform in size, and assembled into a regular checkerboardtype pattern that extends beyond the source area of a domestic well.

- Domestic wells are assumed to be located at the center of a property lot and are constructed as described above; the flow field of one domestic well is here assumed to be independent of the location of other domestic wells.

- Each property lot has one drainfield; drainfields are uniformly sized and square-shaped, but their exact location is unknown; the location is assumed to be anywhere within the property lot with equal probability; the drainfield has a minimum separation distance (see below) from the property lot boundaries.
With these simplifying assumptions, we build a rigorous stochastic model to determine the probability that a septic drainfield is at least partially included in the source area of a domestic well. Groundwater flow direction and septic drainfield location are the independent stochastic variables. Aquifer hydraulic properties, lot size (drainfield density), and drainfield size are independent deterministic variables.

\section{Probabilistic spatial analysis}

The probability analysis is done using geospatial modeling and programming tools (here, we use MATLAB). The geospatial model operates on individual spatial objects, such as points, lines, and shapes, defined by the spatial location of their vertices and edges (Worboys and Duckham, 2004). Object properties also include length (for lines and edges) and area (for shapes).

\subsection{Lot simulation}

The geospatial model first generates a set of square shapes ("grid") in a checkerboard pattern, i.e., square edges are shared by adjacent squares. Each square represents a property lot with area $A_{\text {lot }}$ and side-length $L_{\text {lot }}$, where $A_{\text {lot }}=L_{\text {lot }}^{2}$. The domestic well is defined as a point in the center of the central lot (square shape), and its location is defined as the origin $(x=0, y=0)$ of the spatial coordinate system. The coordinate system is oriented parallel to the edges of the square lot shapes. The grid is chosen large enough to ensure that the source area of the domestic well is always located within the grid: Given a set of parameters, the grid extent in the $\mathrm{x}$ - and 


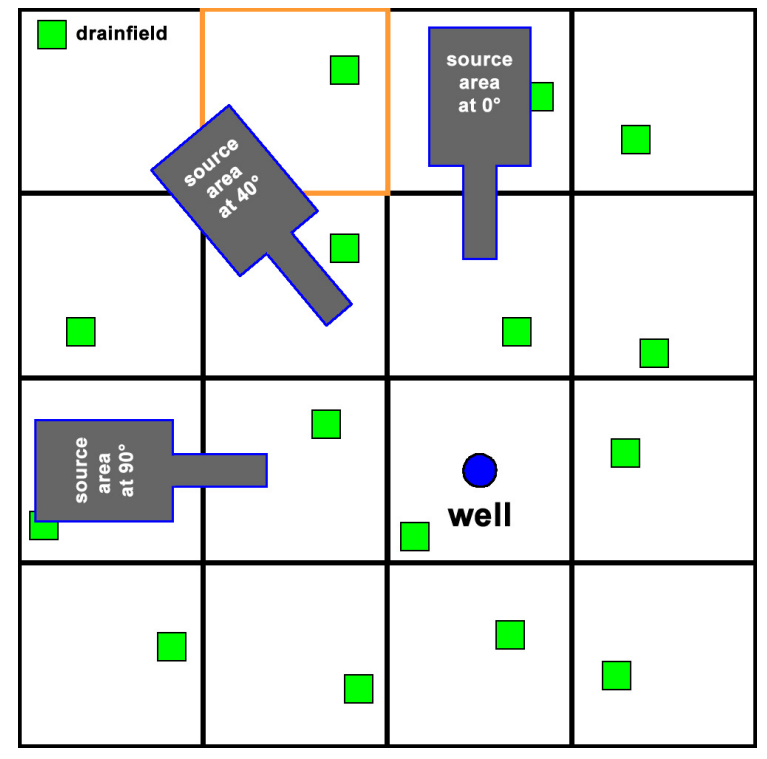

Fig. 3. Schematic representation of the spatial probability analysis concept: A well (blue circle) and its source area (dark grey with blue frame, derived from 3-D simulations by Horn and Harter, 2009) is shown relative to a pattern of individual property lots (black framed). Each lot contains a drainfield of unknown, random location (random samples shown here in green). Since the regional groundwater flow direction is also unknown, the location of the source area relative to the well and the lot grid is unknown too (three possible directions shown here). To estimate the probability that a source area intersects a drainfield, a stochastic integration is performed across all possible configurations. Due to symmetry, the numerical integration only needs to be done for flow directions ranging from $0^{\circ}$ to $90^{\circ}$; therefore, only the upper left part of the lot grid is considered. The lot highlighted in orange is shown in more detail in Fig. 4.

$\mathrm{y}$-direction is set to be at least the distance of the outer edge of the source area to the well. Due to the axis-symmetric lot configuration around the well, only one quarter of the total relevant lot grid needs to be considered. To ensure enough space for wide source areas, we add an additional row and column from the immediately adjacent quarter-domains to the spatial analysis. Figure 3 shows the upper left quarter domain of the lot grid considered.

\subsection{Source area model}

In the second step, the geospatial model defines the source area of the well as a polygon shape with eight vertices and eight edges, corresponding to the merged shape of two rectangles (Figs. 2 and 3). The size of the source area is a deterministic function of the horizontal conductivity, $K_{\mathrm{h}}$, the vertical hydraulic conductivity, $K_{\mathrm{v}}$, and the gravel pack hydraulic conductivity, $K_{\mathrm{g}}$ (Horn and Harter, 2009). The source area shape relative to the domestic well is oriented along the axis of the mean flow direction, $\Phi_{\text {flow }}$, the angle between the $\mathrm{y}$-axis and the flow direction, a stochastic input variable. For

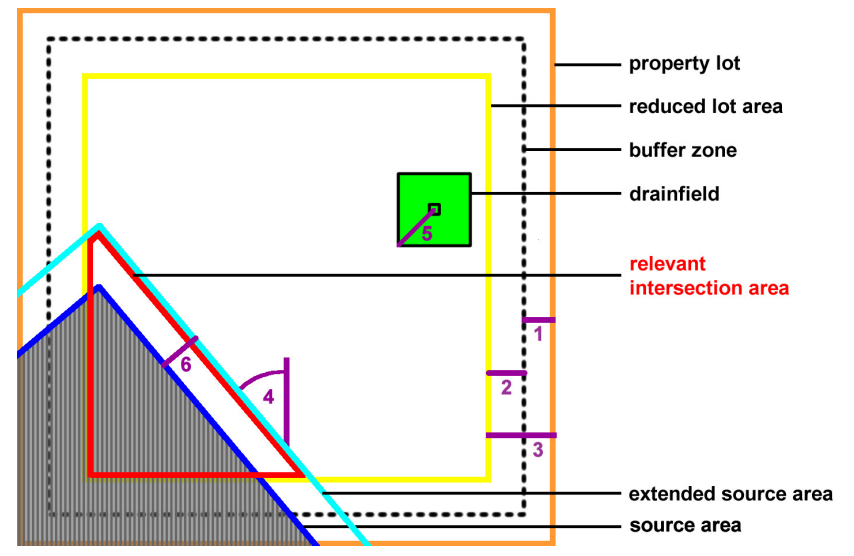

Fig. 4. Source area (grey hashed with blue frame) overlapping a lot (orange square) containing a drainfield (green) at a random position (compare to Fig. 3). The drainfield with the side length $L_{\text {drain }}$ can be located with uniform probability distribution anywhere in the lot with the constraint that the drainfield boundary is separated by a distance of at least $L_{\min }$ (line 1 ) from the lot boundary due to regulatory requirements. For the mathematical analysis, the drainfield is represented as a point and the lot area considered is reduced by half the length of the drainfield, $L_{\text {drain }}$ (line 2). Hence, the total reduction at each lot boundary is the sum of both distances (line 3 , Eq. 2), which leads to the yellow framed reduced lot area relevant for the analysis. Likewise, the source area is extended by $L_{\text {ext }}$ (line 6; Eq. 5), which depends on the distance of the drainfield center to its vertex $\left(L_{\text {drain }}\right.$, line 5$)$ and the flow direction (source area orientation) ( $\Phi_{\text {flow }}$, angle 4$)$. The red framed area is the intersection area $\left(A_{\text {intersect }}\right)$ of the reduced lot area $\left(A_{\text {lot_red }}\right.$, yellow frame) and the extended source area (cyan frame). The probability $p_{\mathrm{i}}$ that the drainfield overlaps with the source area in a given lot $i$ is equal to the ratio of the red intersection area and the reduced lot area marked in yellow.

a given flow direction, the positions of the vertices of the source area polygon are calculated by means of a rotation matrix, $\mathbf{D}_{\Phi}$ :

$\mathbf{D}_{\Phi}=\left(\begin{array}{l}\cos \left(\Phi_{\text {flow }}\right)-\sin \left(\Phi_{\text {flow }}\right) \\ \sin \left(\Phi_{\text {flow }}\right) \cos \left(\Phi_{\text {flow }}\right)\end{array}\right)$.

\subsection{Drainfield location}

Next, the geospatial analysis considers the drainfield location, also a stochastic input variable. Conceptually, the drainfield is represented by a square-shaped area, $A_{\text {drain }}$, with a side length $L_{\text {drain }}$ (Fig. 4). The drainfield cannot be located less than a distance, $L_{\min }$, of $10 \mathrm{ft}(3.05 \mathrm{~m})$ from the property lot boundary, a common regulatory requirement. For the geospatial analysis, we represent the drainfield as a point rather than an area and instead account for the drainfield area via consideration of a reduced area of location within a property lot and an enhanced source area shape. The point representing the drainfield area cannot be located less than a distance, $L_{\text {red }}$, from the property lot boundary: 
$L_{\text {red }}=L_{\text {min }}+0.5 \cdot L_{\text {drain }}$.

The area within which the center point of the drainfield can be located, which is thus relevant for the geospatial analysis, is consequently defined by a square shape centered within the lot shape that has a side length of

$L_{\text {lot } \_ \text {red }}=L_{\text {lot }}-2 \cdot L_{\text {red }}$

and a reduced lot area, $A_{\text {lot red }}$ :

$A_{\text {lot_red }}=L_{\text {lot_red }}^{2}$.

With the drainfield represented by its center-location, we extend the domestic well source area shape on all sides by the distance $L_{\text {ext }}$ : in cases of the source area orientation being parallel to the sides of the drainfield $\left(\Phi_{\text {flow }}=0^{\circ}\right.$ and $\Phi_{\text {flow }}=90^{\circ}$ ), this distance equals half the side length of the drainfield $\left(0.5 \times L_{\text {drain }}\right)$. If $\Phi_{\text {flow }}$ is other than $0^{\circ}$ and $90^{\circ}$, $L_{\text {ext }}$ depends on $\Phi_{\text {flow }}$ and can be geometrically derived by

$L_{\text {ext }}=\sin \left(45^{\circ}+\Phi_{\text {flow }}\right) \cdot L_{\text {diag }}$

where $L_{\text {diag }}$ is half the diagonal of the drainfield. Figure 4 illustrates these geometric considerations for an arbitrary flow direction $\Phi_{\text {flow }}$ of $40^{\circ}$.

The drainfield location within the lot area is considered to follow a uniform probability distribution, i.e., any drainfield location within the allowable lot area is equally probable. It then follows that the probability, $p(i)$, that a given source area intersects a fraction or all of a drainfield within a particular property lot $i$ is equal to the ratio of the area of intersection of the extended source area shape with the reduced lot area in $i, A_{\text {intersect }}(i)$, and $A_{\text {lot_red }}$ (Fig. 4):

$p_{\mathrm{i}}=\frac{A_{\text {intersect }}(i)}{A_{\text {lot_red }}}$.

For all non-overlapping grid cells, we have $p_{\mathrm{i}}=0$. We further define the complementary probability, $\bar{p}_{\mathrm{i}}$, as the probability that the source area does not intersect with the drainfield system in lot $i$ :

$\bar{p}_{\mathrm{i}}=1-p_{\mathrm{i}}$.

The probability, $p\left(\Phi_{\text {flow }}\right)$, that the source area intersects with at least one drainfield center at a given flow direction, $\Phi_{\text {flow }}$, is the complementary of the probability that the extended source area intersects none of the drainfield centers in the entire lot grid:

$p\left(\Phi_{\text {flow }}\right)=1-\prod_{\mathrm{i}_{1}}^{n_{\mathrm{L}}} \bar{p}_{\mathrm{i}}$

where the index $i$ is running from one to the number of lots in the grid, $n_{\mathrm{L}}$. Note that, for all non-overlapping lots, $\bar{p}_{\mathrm{i}}=1$.
Table 1. The stochastic spatial analysis is performed for various combinations of the horizontal hydraulic conductivity, $K_{\mathrm{h}}$, the vertical hydraulic conductivity, $K_{\mathrm{V}}$, and the gravel pack hydraulic conductivity, $K_{\mathrm{g}}$. All values are in units of $\left[\mathrm{m} \mathrm{d}^{-1}\right]$.

\begin{tabular}{lll}
\hline$K_{\mathrm{h}}$ & $K_{\mathrm{V}}$ & $K_{\mathrm{g}}$ \\
\hline 1 & 0.2 & $50,125,250,500,750,1000$ \\
1 & 0.5 & $50,125,250,500,750,1000$ \\
3 & 0.6 & $50,125,250,500,750,1000$ \\
3 & 1.5 & $50,125,250,500,750,1000$ \\
5 & 1 & $50,125,250,500,750,1000$ \\
5 & 2.5 & $50,125,250,500,750,1000$ \\
10 & 2 & $50,125,250,500,750,1000$ \\
10 & 5 & $50,125,250,500,750,1000$ \\
30 & 6 & $50,125,250,500,750,1000$ \\
30 & 15 & $50,125,250,500,750,1000$ \\
100 & 20 & $125,250,500,750,1000$ \\
100 & 50 & $125,250,500,750,1000$ \\
300 & 60 & $500,750,1000$ \\
300 & 150 & $500,750,1000$ \\
\hline
\end{tabular}

\subsection{Flow direction}

We assume that there is no prior information on the groundwater flow direction and, hence, assume that the probability of $\Phi_{\text {flow }}$ is uniform within $0^{\circ}$ and $360^{\circ}$. Having determined the intersection probability $p\left(\Phi_{\text {flow }}\right)$ for each discrete flow direction step, and each flow direction being equiprobable (in a regional sense), we determine the total probability of intersection, $p_{\mathrm{T}}$, by taking the expected value of the individual probabilities:

$p_{\mathrm{T}}=\left\{p\left(\Phi_{\text {flow }}\right)\right\}=\frac{1}{360} \cdot \int_{\Phi_{\text {flow }}=0}^{360} p\left(\Phi_{\text {flow }}\right) d \Phi_{\text {flow }}$

where \{\} indicates expected values.

The stochastic spatial analysis with random flow direction, $\Phi_{\text {flow }}$, and random drainfield location in each of the lots of the simulation lot grid, is implemented using numerical integration (Eq. 9). Due to symmetry consideration, the complete stochastic solution is obtained numerically by solving the problem for $0^{\circ}<\Phi_{\text {flow }}<90^{\circ}$. The numerical integration is here performed by considering a finite number of equally spaced directions (Fig. 3) in user-defined steps of $x^{\circ}$ from $\Phi_{\text {flow }}=0^{\circ}$ to $\Phi_{\text {flow }}=90^{\circ}$. For our analysis, we chose $1^{\circ}$ increments.

\subsection{Hydraulic conductivities, lot and drainfield sizes}

This stochastic spatial analysis is performed for a wide range of hydraulic conditions (Table 1), as well as various lot and drainfield sizes: $K_{\mathrm{h}}$ is assumed to range from 1 to $300 \mathrm{~m} \mathrm{~d}^{-1}$; two anisotropy ratios, $K_{\mathrm{v}}: K_{\mathrm{h}}$, of 1:2 and 1:5, which are representative for alluvial aquifers, are chosen; $K_{\mathrm{g}}$ is set to values ranging from $50 \mathrm{~m} \mathrm{~d}^{-1}$ to $1000 \mathrm{~m} \mathrm{~d}^{-1}$, but at least as large 
as $K_{\mathrm{h}}$. We further consider a range of lot sizes from $2023 \mathrm{~m}^{2}$ ( 1 acre), which is the minimum lot size typically required for properties to have septic systems, to nearly $353300 \mathrm{~m}^{2}$, which represents an approximate average density of domestic wells in our exemplary study area (Burow et al., 2004). The following lot sizes were chosen:

- $2023 \mathrm{~m}^{2}$ (L1). Lots, which were established before the current regulations regarding minimum required lot sizes of 1 acre (see below) were introduced, are sometimes smaller than 1 acre; here we assume a hypothetical neighborhood of 0.5 acre lots.

- $4047 \mathrm{~m}^{2}$ (L2). This size equals the minimum allowable lot size of 1 acre for rural-residential areas in the study area.

- $35330 \mathrm{~m}^{2}$ (L3). This area is determined by dividing the example study area by 6510 wells (estimated number of domestic wells) and multiplying the result by 10 to represent areas with an increased population density; this size is equal to 8.7 acre.

- $53000 \mathrm{~m}^{2}$ (L4). The study area is divided by 4340 wells (number of domestic wells with well logs) and multiplied by 10 to represent areas with an increased population density. The resulting lot size is 13.1 acre.

- $80937 \mathrm{~m}^{2}$ (L5). This area corresponds to an area of 20 acres and was chosen since many rural regulations use this area as minimum required lot size in areas zoned as agricultural.

- $353300 \mathrm{~m}^{2}$ (L6). This size corresponds to the estimated current average density of domestic wells in the example study area and presumably of the drainfield density (one system per well).

For the drainfield area, we use three values, $40 \mathrm{~m}^{2}$ (D1), $70 \mathrm{~m}^{2}$ (D2) and $100 \mathrm{~m}^{2}$ (D3). The three values cover a typical range required for the drainfield of a household septic system. Equation (9) is evaluated for all possible combinations of the six lot sizes, the three drainfield areas, as well as the various combinations of $K_{\mathrm{h}}, K_{\mathrm{g}}$, and the anisotropy ratios (Table 1). This leads to 1368 lot-drainfield-conductivitycombinations being analyzed.

\section{Results}

The intersection probability, $p_{\mathrm{T}}$, represents the probability that a domestic well pumps water that is at least partially recharged by a septic drainfield system. The probability varies from $0.6 \%$ for large lots (low septic system densities) and low hydraulic conductivities, $K_{\mathrm{h}}$, to near $100 \%$ for small lot sizes and high hydraulic conductivities. Figure 5 shows the results for all lot-drainfield-aquifer configurations.

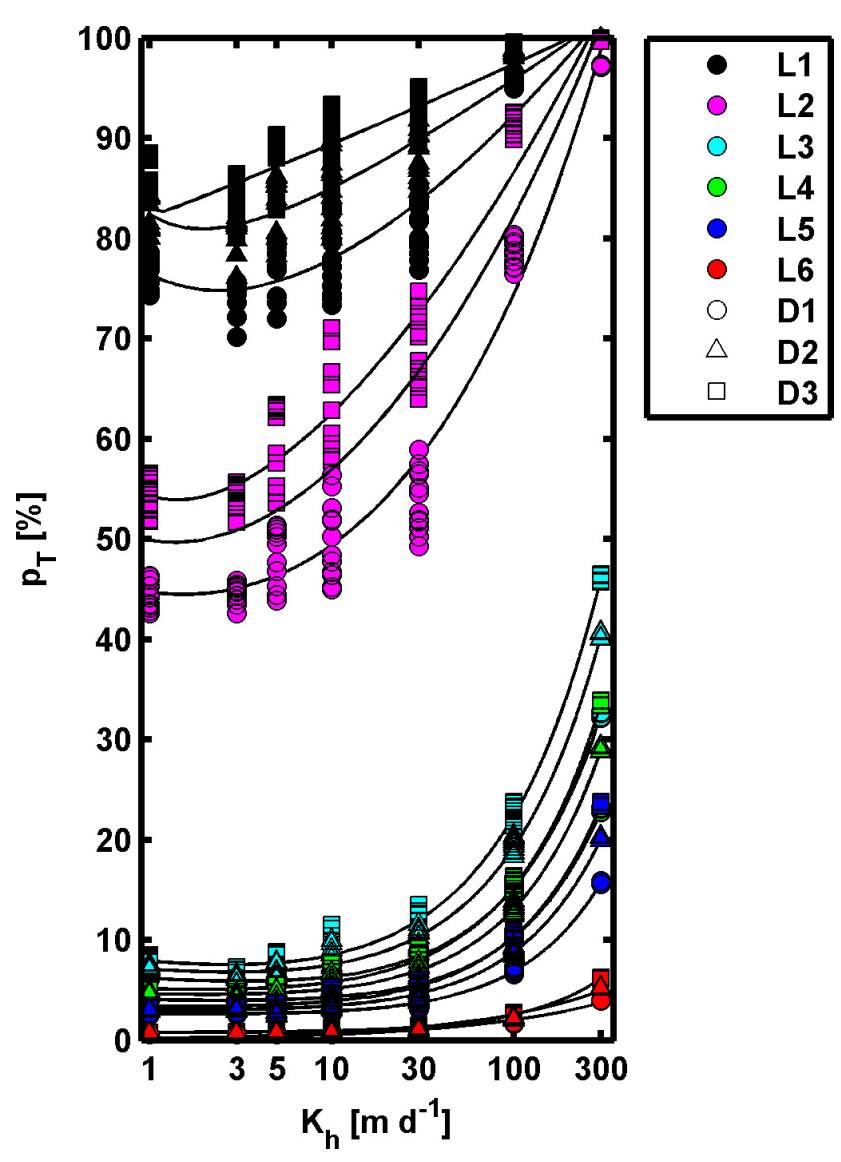

Fig. 5. Resulting intersection probabilities depending on $K_{\mathrm{h}}$ on a logarithmic scale for all analyzed aquifer and septic system configurations. The color of the markers indicates the various lot sizes (L1-L6; see text for further specifications). The form of the markers indicates the three drainfield sizes. The range of $p_{\mathrm{T}}$ for a given $K_{\mathrm{h}}$, lot and drainfield size stems from the variation of $K_{\mathrm{g}}$ and - to a much smaller extent - of $K_{\mathrm{V}}$ (see Fig. 6). The black lines correspond to the exponential fits (Eq. 10) presented in Table 2.

Under conditions typical of alluvial aquifers, the intersection probability, $p_{\mathrm{T}}$, is primarily a function of the lot size and, hence, drainfield system density. The smaller the lot size, the higher the risk is of a domestic well partially pumping septic leachate, independent of aquifer conditions. For the half acre lots (L1), $p_{\mathrm{T}}$ is well over $70 \%$, regardless of $K_{\mathrm{h}}$, anisotropy ratio, $K_{\mathrm{g}}$, or drainfield system size. At very high aquifer and gravel pack hydraulic conductivities, the intersection probability for L1-lots is nearly $100 \%$.

For a given lot and drainfield set-up, the total intersection probability, $p_{\mathrm{T}}$, is most sensitive to aquifer hydraulic conductivity, $K_{\mathrm{h}}$, and less sensitive to aquifer anisotropy and gravel pack hydraulic conductivity (Fig. 5). At higher $K_{\mathrm{h}}$, the source area is significantly longer (albeit more narrow), which results in an eightfold, non-linear increase in $p_{\mathrm{T}}$. The total intersection probability is least sensitive to $K_{\mathrm{h}}$ for the smallest lots, where $p_{\mathrm{T}}$ is always very high; in contrast, $p_{\mathrm{T}}$ is 

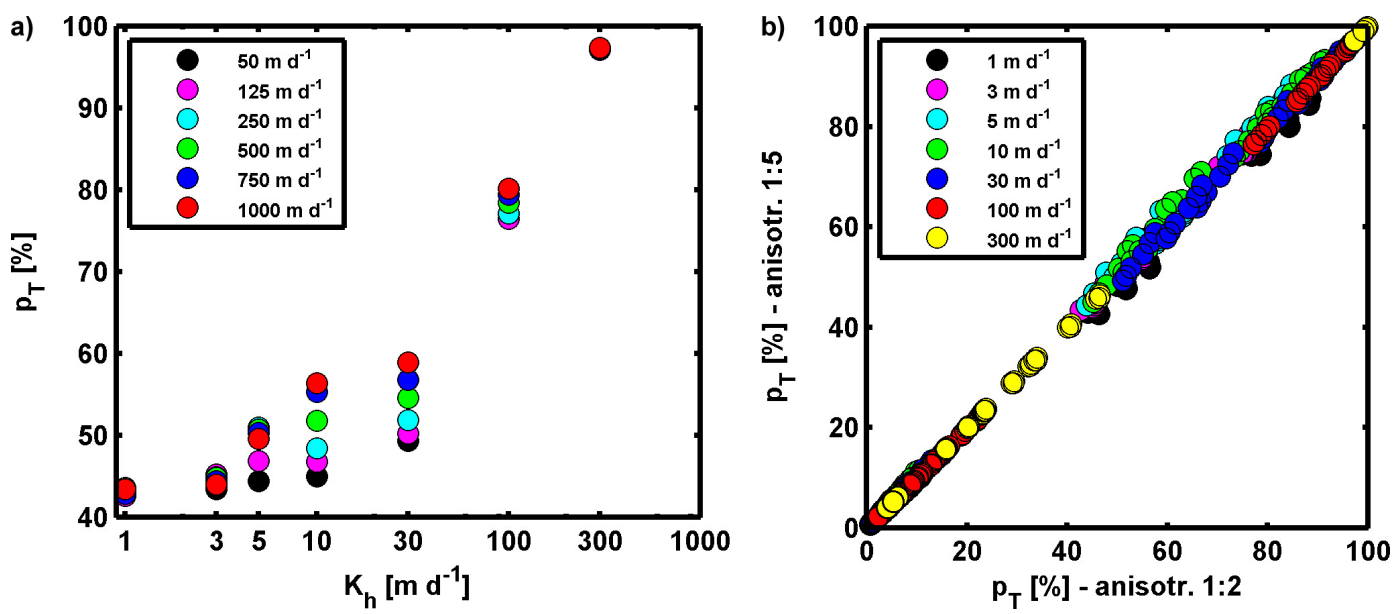

Fig. 6. (a) The influence of the hydraulic conductivity of the gravel pack $\left(K_{\mathrm{g}}\right)$ on the intersection probability, $p_{\mathrm{T}}$, depending on the hydraulic conductivity, $K_{\mathrm{h}}$. The colors indicate different values of $K_{\mathrm{g}}\left[\mathrm{m} \mathrm{d}^{-1}\right]$. Example for a lot size of 1 acre (L2), a drainfield size of $40 \mathrm{~m}^{2}$ (D1), and an anisotropy ratio of 1:5. The effect of $K_{\mathrm{g}}$ on $p_{\mathrm{T}}$ for the other lot-drainfield-configurations is similar. (b) The intersection probabilities for aquifers with an anisotropy ratio of $1: 5 \mathrm{vs}$. those with an anisotropy ratio of 1:2. The colors indicate different values for $K_{\mathrm{h}}\left[\mathrm{m} \mathrm{d}^{-1}\right]$. All conductivity-lot-drainfield-configurations are considered.

most sensitive to $K_{\mathrm{h}}$ in areas with large lots and large drainfield size.

For all lot sizes, the total intersection probability is relatively insensitive to $K_{\mathrm{h}}$, if $K_{\mathrm{h}}$ is less than $10 \mathrm{~m} \mathrm{~d}^{-1}$. This insensitivity is due to the fact that the source area in low permeable aquifers, given the amount of recharge assumed here, is relatively short (and wide), and it is close to the production well. Because of the proximity to the well, few if any neighboring lots are intersected by the source area. Hence, $p_{\mathrm{T}}$ is controlled primarily by the ratio of drainfield system size to lot size. The non-linear relationships between $K_{\mathrm{h}}$ and $p_{\mathrm{T}}$ for the various lot-drainfield configurations can be expressed mathematically by the following fitting function on a logarithmic scale:

$p_{\mathrm{T}}\left(K_{\mathrm{h}}\right)=a \cdot \exp \left(b \cdot \log _{10}\left(K_{\mathrm{h}}\right)\right)+c \cdot \exp \left(d \cdot \log _{10}\left(K_{\mathrm{h}}\right)\right)$.

The regression model is shown in Fig. 5; the fitted parameters for the 18 lot-drainfield configurations are shown in Table 2.

Although the gravel pack hydraulic conductivity, $K_{\mathrm{g}}$, has less influence than $K_{\mathrm{h}}$ on $p_{\mathrm{T}}$, higher gravel pack hydraulic conductivities are clearly associated with a higher risk of intersection. Figure 6a shows an example for a small lot (L2) and a small drainfield (D1). In this example, $p_{\mathrm{T}}$ varies by over $8 \%$ as a result of uncertainty about $K_{\mathrm{g}}\left(K_{\mathrm{h}}\right.$ is assumed to be $10 \mathrm{~m} \mathrm{~d}^{-1}$ ). Considering all configurations, $p_{\mathrm{T}}$ may vary by up to $15 \%$ across a reasonable range of $K_{\mathrm{g}}$, at known $K_{\mathrm{h}}$ values (L2; see Fig. 5). Total intersection probability is most sensitive to $K_{\mathrm{g}}$ in small lot sizes (L1 and L2) with large drainfield size (D3), and at the higher anisotropy ratio of 1:5. In contrast, $p_{\mathrm{T}}$ is relatively insensitive to $K_{\mathrm{g}}$ in large lots. In Fig. 5, the sensitivity of $p_{\mathrm{T}}$ to $K_{\mathrm{g}}$ is indicated by the range of $p_{\mathrm{T}}$ values plotted for a given lot-drainfield configuration (multiple symbols of the same color and shape). For
Table 2. Parameters and quality measures for the intersection probability fits (Eq. 10) depending on lot or septic systems densities, respectively, (L1-L5) and drainfield sizes (D1, D2, D3). For specifications of lot and drainfield sizes, please refer to Sect. 4.5. $R^{2}$ is the coefficient of determination; RMSE is the root-mean-squared error.

\begin{tabular}{lrrrrrc}
\hline configuration & $a$ & $b$ & $c$ & $d$ & $R^{2}$ & RMSE \\
\hline L1, D1 & 19.51 & -1.13 & 56.87 & 0.23 & 0.89 & 2.88 \\
L1, D2 & 8.01 & -2.59 & 74.38 & 0.13 & 0.87 & 2.54 \\
L1, D3 & 4.49 & -58.42 & 82.10 & 0.09 & 0.84 & 2.20 \\
L2, D1 & 32.32 & -0.37 & 12.36 & 0.78 & 0.96 & 3.37 \\
L2, D2 & 19.35 & -0.91 & 30.53 & 0.48 & 0.95 & 3.74 \\
L2, D3 & 11.94 & -1.73 & 42.37 & 0.36 & 0.94 & 3.88 \\
L3, D1 & 5.93 & -0.24 & 0.24 & 1.94 & 0.99 & 0.61 \\
L3, D2 & 6.69 & -0.28 & 0.40 & 1.83 & 0.99 & 0.80 \\
L3, D3 & 7.32 & -0.34 & 0.58 & 1.74 & 0.99 & 0.95 \\
L4, D1 & 3.95 & -0.14 & 0.10 & 2.12 & 0.99 & 0.40 \\
L4, D2 & 4.47 & -0.15 & 0.17 & 2.04 & 0.99 & 0.53 \\
L4, D3 & 4.90 & -0.17 & 0.23 & 1.97 & 0.99 & 0.64 \\
L5, D1 & 2.61 & -0.11 & 0.06 & 2.21 & 0.99 & 0.28 \\
L5, D2 & 2.97 & -0.10 & 0.09 & 2.15 & 0.99 & 0.36 \\
L5, D3 & 3.27 & -0.10 & 0.11 & 2.11 & 0.99 & 0.43 \\
L6, D1 & 0.43 & -50.76 & 0.17 & 1.25 & 0.93 & 0.25 \\
L6, D2 & 0.18 & 1.33 & 0.50 & -41.24 & 0.95 & 0.30 \\
L6, D3 & 0.77 & -0.01 & 0.02 & 2.32 & 0.99 & 0.11 \\
\hline
\end{tabular}

the largest lots (L6) and the smallest drainfields (D1), the range of $p_{\mathrm{T}}$ between lowest and highest $K_{\mathrm{g}}$ is only $0.1 \%$. The total intersection probability, $p_{\mathrm{T}}$, is most sensitive to $K_{\mathrm{g}}$ in the middle of the investigated $K_{\mathrm{h}}$-range $\left(10\right.$ and $\left.30 \mathrm{~m} \mathrm{~d}^{-1}\right)$, while almost no sensitivity to $K_{\mathrm{g}}$ is observed at either very low (less than $5 \mathrm{~m} \mathrm{~d}^{-1}$ ) or very high $\left(100 \mathrm{~m} \mathrm{~d}^{-1}\right.$ or more) values of $K_{\mathrm{h}}$. 
The anisotropy ratio of the aquifer hydraulic conductivity has a relatively small influence on $p_{\mathrm{T}}$. Figure $6 \mathrm{~b}$ compares the probabilities resulting from the scenarios with an anisotropy ratio of $1: 2$ to those with an anisotropy ratio of 1:5; the different $K_{\mathrm{h}}$-values are indicated. For scenarios resulting in $p_{\mathrm{T}}$-values between $40 \%$ and $90 \%$ (L1-L2), the anisotropy ratio of $1: 5$ often causes a slight increase in the intersection probability, but not exceeding $5 \%$. The higher $K_{\mathrm{g}}$ relative to $K_{\mathrm{h}}$, the larger is this difference. In these cases of a large $K_{\mathrm{g}}$ and a $K_{\mathrm{h}}$ not higher than $30 \mathrm{~m} \mathrm{~d}^{-1}$, the higher anisotropy ratio (1:5) leads to an increase in the elongated portion of the source area shape, due to relatively higher gravel pack capture, thus increasing the risk of intersection with a drainfield. For smaller differences between $K_{\mathrm{g}}$ and $K_{\mathrm{h}}$, the effect by the anisotropy ratio is less pronounced or even slightly reversed. $K_{\mathrm{h}}$-values of $1 \mathrm{~m} \mathrm{~d}^{-1}$ principally result in slightly lower probabilities for an anisotropy ratio of 1:5. For this very small hydraulic conductivity, the elongated extension of the source area due to the gravel pack, which is the part of the source area shape most affected by the anisotropy ratio, does not exist.

Drainfield system size has a greater influence on $p_{\mathrm{T}}$ than the anisotropy ratio (within the parameter ranges chosen): Larger drainfield system size results in an increased intersection probability. For $100 \mathrm{~m}^{2}$ drainfield systems, the intersection probability is up to $16 \%$ higher than for $40 \mathrm{~m}^{2}$ systems. Drainfield system size is most influential when the lot size is small. In case of the largest lots (much larger than $100000 \mathrm{~m}^{2}$ ), however, the drainfield system size has negligible influence on the intersection probability (range of less than $1 \%$ between drainfield sizes).

\section{Discussion and conclusions}

The probabilistic spatial analysis demonstrates that domestic wells have a wide range of intersection probabilities with septic system leachate, controlled primarily by lot density and horizontal hydraulic conductivity of the aquifer. The results can be grouped into three general categories driven by lot size:

- Spatial septic system densities of approximately one septic system per $0.5-5$ acre $\left(\sim 2000-20000 \mathrm{~m}^{2}\right)$ yield a very high probability of intersection with at least 4 in 10 domestic wells pumping water that is partially recharged from septic systems.

- For septic system densities on the order of one system per 5-20 acres $\left(\sim 40000-100000 \mathrm{~m}^{2}\right), p_{\mathrm{T}}$ is on the order of 5-10\% for medium hydraulic conductivities.

- When septic system density is very low $(\sim$ one per $400000 \mathrm{~m}^{2}$ ), the probability of intersection decreases to approximately 1 in 100 domestic wells pumping some portion of septic system leachate.
Hydraulic conductivity weighs into this classification to some degree, increasing the probability of intersection for highly permeable aquifers and gravel packs around the well, while in aquifers with relatively low hydraulic conductivity, fewer wells tend to be affected than indicated by the approximate ranges given above. Aquifer anisotropy and gravel pack hydraulic conductivity have only limited influence. In practice, the evaluation of risk presented here can be complemented with an evaluation of the area of domestic wells likely having a source area partially overlapping with property lots containing septic systems, given the particular typical depth range of domestic wells and general groundwater direction.

Our results are specific to the chosen pumping rate, screen interval length and gravel pack length. Pumping rate will have a larger effect on interception risk than screen length, since the size of the source area is proportional to the pumping rate (in a uniform recharge area). Screen length and gravel pack length, for a given pumping rate, affect the shape but not the size of the source area. Thus, similar risk would be obtained as that reported here. Results shown in Figs. 5 and 6 are therefore widely applicable.

Lot size, septic drainfield configuration, and local specificity of the groundwater flow field further affect the probability that a domestic well partially intercepts septic leachate. However, the regular squared lot shapes provide a good first order approximation of property lot distributions and hence septic drainfield distribution relative to well location. Our method could be further adopted for other lot shapes and drainfield configurations than considered in our general model.

It is useful to compare the risk obtained from the probabilistic, stochastic spatial analysis against some simple, yet important mass balance-based risk indicators: The fraction of areal recharge across all lots that becomes domestic well water, $Q_{\mathrm{P}} / Q_{\mathrm{R}}$, is defined as the ratio of total domestic pumpage, $Q_{\mathrm{P}},\left(1234 \mathrm{~m}^{3} \mathrm{lot}^{-1}\right)$ to total recharge flux, $Q_{\mathrm{R}}$, from residential lots (varies as a function of lot size) in a (hypothetical) infinite domain.

The ratio $Q_{\mathrm{P}} / Q_{\mathrm{R}}$ is $91.1 \%, 45.6 \%, 5.2 \%, 3.5 \%, 2.3 \%$, and $0.5 \%$ for L1 through L6 lot sizes. Lacking any information about septic drainfields and conservatively assuming that all drainfield recharge poses a high risk of septic contamination, this ratio can be interpreted statistically as a (regional) probability that a well intercepts a septic leachate plume. Despite the very conservative assumption, these ratios indeed provide a good order-of-magnitude approximation of the risk estimates obtained from the probabilistic spatial analysis (compare to Fig. 5). However, our spatial analysis demonstrates that simple mass balance ratios are insufficient to capture actual risk: at intermediate and high hydraulic conductivity in the aquifer, which results in long and narrow recharge source areas for each well, risk drastically increases the probability of intersection with a septic drainfield plume. This increase stems from the fact that $Q_{\mathrm{P}} / Q_{\mathrm{R}}$ 
does not account for the source area of a well intersecting multiple properties, each with its own septic drainfield.

For intermediate and large lots, $Q_{\mathrm{P}} / Q_{\mathrm{R}}$ only provides a lower bound estimate, although it may seem to be an overly conservative estimate. Only for L1, and to a much lesser degree also for $\mathrm{L} 2$, the risk computed from the statistical spatial analysis is lower than the value computed from $Q_{\mathrm{P}} / Q_{\mathrm{R}}$, except at high $K_{\mathrm{h}}$. In small lots, the geometric shape of the recharge source area significantly lowers the potential risk compared to the simple $Q_{\mathrm{P}} / Q_{\mathrm{R}}$ model.

Some researchers have used mass balance models, sometimes coupled to groundwater models, to assess the risk from septic systems (e.g., Trela and Douglas, 1978; Lowe et al., 2003; Bishop et al., 2007; Lowe et al., 2011). Consider the fraction of septic recharge in the total recharge, $Q_{\mathrm{S}} / Q_{\mathrm{R}}$, where $Q_{\mathrm{S}}$ is the septic drainfield recharge. Given the uniform recharge assumption in our model, the recharge from the area immediately underlying the drainfield is $2.2 \%, 3.8 \%$, and $5.4 \%$ of domestic water use, respectively, for D1, D2, and D3. Typical sewage return flow, however, is at least $25 \%$ of total domestic water use (the remainder of the domestic water use ultimately transpires from lawns in much of the warmer regions in the US). A $25 \%$ fraction of total pumpage recharged from the septic drainfield $\left(308 \mathrm{~m}^{3} \mathrm{yr}^{-1}\right)$ represents $22.8 \%, 11.4 \%, 1.3 \%, 0.9 \%, 0.6 \%$, and $0.1 \%$ of the total lot recharge for L1 through L6 lot sizes. Multiplying these latter fractions, $Q_{\mathrm{S}} / Q_{\mathrm{R}}$, with the respective lot size-dependent fraction of domestic pumping, $Q_{\mathrm{P}} / Q_{\mathrm{R}}$, yields the (instantaneously) mixed fraction of septic leachate in the domestic well water: $20.8 \%, 5.2 \%, 0.07 \%, 0.03 \%, 0.01 \%$, and $0.001 \%$ for L1 through L6, respectively. Using these mixing model-based ratios to evaluate the risk of domestic wells intercepting septic leachate leads to substantial, order-ofmagnitude underestimation of the actual risk.

The analysis has several limitations that must be considered. As stated above, the uniform recharge assumption means that recharge from D1, D2, and D3 drainfield sizes are only $10 \%$ to $25 \%$ of realistically expected drainfield recharge. In particular for L1 and L2, our estimates must therefore be considered to be low. For larger lot sizes, this simplification is less significant. Furthermore, our recharge is based on typical recharge from lawn irrigation, typical drainfield discharge, and recharge from surrounding irrigated agricultural land in relatively surface water-rich, semi-arid climates (Burow et al., 2004) or in humid regions with high precipitation. Elsewhere, recharge rates in areas surrounding a septic drainfield are significantly smaller than $0.7 \mathrm{~m} \mathrm{yr}^{-1}$. Where recharge rates from septic drainfields are nearly an order of magnitude higher than in surrounding areas due to low precipitation, lack of irrigation, or large areas of surface sealing from pavement and buildings (i.e., particularly where lot density is high), $p_{\mathrm{T}}$-values are likely much higher than estimated above due to the focused contribution of the septic drainfield recharge.
Our analysis also does not consider the effects of aquifer heterogeneity and macro-dispersion on the source area. This is a reasonable simplification, since aquifer heterogeneity adds uncertainty in the prediction of transport pathways and duration, but does not change the long-term recharge contribution from septic drainfields and hence does not change the overall size of the source area, only its actual shape and location (Kunstmann and Kastens, 2006). Since our analysis is already probabilistic with respect to the exact shape and location relative to the lot shape, aquifer heterogeneity would not add to the reported uncertainty. However, spatial variability among lot sizes and shapes, and in septic system densities, not considered here, does affect actual contamination risk.

From a risk management perspective, our results raise significant concern about allowing septic systems to be built on lots smaller than 20 acres ( $8 \mathrm{ha}$ ). Under most aquifer conditions, an assembly of lots that small in size (sub-rural or sub-urban subdivisions, ranchettes) is associated with a potentially significant risk for impacting well water quality in domestic wells. From a public policy perspective, the results imply that regulators and public health agencies interested in addressing septic contamination of domestic wells would first target regions with relatively high lot and septic system densities. We caution, however, that the above total intersection probabilities are not equal to the risk for domestic well contamination. The contamination risk is determined not only by the total intersection probability, but also by contaminant concentration in the septic leachate (source strength), the amount of pumped water that originates from the septic system relative to the total amount of water pumped (dilution), and by the degree to which contaminants released from the drainfield system are inactivated (pathogens) or degraded (chemicals) along their travel path to the well (attenuation).

Nitrate- $\mathrm{N}$ is usually considered one of the principal indicators of pollution from septic systems. Hence, most detailed evaluations for maximum septic system densities have been based on groundwater flow models coupled with a mass balance approach for nitrate-N. Generally, the contamination risk is significantly lower for nitrate-N than shown in Fig. 5. The regulatory limit for nitrate- $\mathrm{N}\left(10 \mathrm{mg} \mathrm{Nl}^{-1}\right)$ is approximately one order of magnitude lower than typical septic leachate concentrations. While not attenuated in many unconfined alluvial aquifers (Robertson et al., 1991; Robertson and Cherry, 1992; Pang et al., 2006), dilution of the septic leachate with water from non-septic recharge within the domestic well itself will often reduce nitrate-N levels to below the MCL. Where the lot density is high, or where the ratio $Q_{\mathrm{P}} / Q_{\mathrm{R}}$ is high due to low recharge outside the septic drainfield, the dilution effect is insufficient, as shown by field surveys (Arnade, 1999; Whitehead and Geary, 2000; Drake and Bauder, 2005; Verstraeten et al., 2005). Lowe et al. (2003, 2011) and Bishop et al. (2007), for example, recommended a maximum density of one system per 2.5 to 15 acre to prevent groundwater contamination with regard to nitrate- $\mathrm{N}$ in (semi-)rural areas on unconsolidated basin-fill of fluvial and 
lacustrine deposits and on alluvial fans. Our study indicates that this is not sufficient to minimize the probability of direct intersection of a well source area with a drainfield. We note that, in areas predominantly under intensive agricultural use, septic system leachate is a very small fraction of the total nitrogen load to groundwater (Dubrovsky et al., 2010; Harter et al., 2012).

The highest risk exists for contaminants frequently released from septic drainfield systems at a high dose relative to drinking water standards and subject to very limited attenuation. Where coarse-textured or fractured soils overlay sandy or gravelly aquifers, this includes some pathogenic viruses and bacteria (Scandura and Sobsey, 1997). The MCLG-value (Maximum Contaminant Level Goal) of the US EPA for total coliforms and microbial contaminants like Cryptosporidium is less than one per liter (US EPA, 2003b). Particularly in improperly operated drainfields, pathogens can be released in high concentrations (e.g., Alhajjar et al., 1988; Nicosia et al., 2001; Lowe et al., 2003; Ahmed et al., 2005). Even if only a small fraction of the domestic well water originates from septic leachate, such capture is almost certain to carry pathogens, pathogen indicators or low concentration of organic micropollutants such as PhaCs, personal care products, and endocrine-disrupting chemicals, some of which can be transported over long distances (Carrara et al., 2008; Swartz et al., 2006; Godfrey et al., 2007; Rudel et al., 1998; Osenbrück et al., 2007). Effects of long-term exposure and synergistic effects on the human health of various pollutants in low concentrations are not always known; research therefore progressively focuses on these wastewater compounds (Musolff, 2009; Stanford et al., 2010). With respect to these substances, the above values of $p_{\mathrm{T}}$ may be considered a close approximation of the contamination risk (on a per well basis) and of the fraction of contaminated wells within a large group of domestic wells, e.g., on a countywide basis.

Finally, this study indicates the need for a dual perspective on septic leachate contamination of groundwater. For regional groundwater basin management and water quality protection, a mass balance and mixing model approach provides an overall measure of impact to groundwater, particularly with respect to salts and nitrate. Our risk analysis further provides a basis for estimating the fraction of domestic wells affected by septic leachate contamination. At the local scale or from the perspective of a well owner, guidelines protective of regional water quality may not be effective at preventing contamination of individual wells. For a well owner, our analysis provides an estimate of the risk of contamination at an individual well, after taking into consideration the source strength and potential fate of contaminants.
Table A1. List of variables, parameters and symbols used.

\begin{tabular}{|c|c|c|}
\hline variable & unit description & \\
\hline$A_{\text {drain }}$ & {$\left[\mathrm{m}^{2}\right]$} & drainfield area \\
\hline$A_{\text {intersect }}$ & {$\left[\mathrm{m}^{2}\right]$} & $\begin{array}{l}\text { intersection area (extended } \\
\text { source area/reduced lot) }\end{array}$ \\
\hline$A_{\text {lot }}$ & {$\left[\mathrm{m}^{2}\right]$} & lot area \\
\hline$A_{\text {lot_red }}$ & {$\left[\mathrm{m}^{2}\right]$} & area of reduced lot \\
\hline $\mathbf{D}_{\Phi}$ & {$[-]$} & rotation matrix \\
\hline D1, D2, D3 & {$[-]$} & $\begin{array}{l}\text { symbol for drainfield sizes } \\
\text { of } 40,70 \text { and } 100 \mathrm{~m}^{2}\end{array}$ \\
\hline$K_{\mathrm{h}}$ & {$\left[\mathrm{m} \mathrm{d}^{-1}\right]$} & $\begin{array}{l}\text { horizontal hydraulic } \\
\text { conductivity of the aquifer }\end{array}$ \\
\hline$K_{\mathrm{V}}$ & {$\left[\mathrm{m} \mathrm{d}^{-1}\right]$} & $\begin{array}{l}\text { vertical hydraulic } \\
\text { conductivity of the aquifer }\end{array}$ \\
\hline$K_{\mathrm{g}}$ & {$\left[\mathrm{m} \mathrm{d}^{-1}\right]$} & $\begin{array}{l}\text { hydraulic } \\
\text { conductivity of the gravel } \\
\text { pack }\end{array}$ \\
\hline$L_{\text {diag }}$ & {$[\mathrm{m}]$} & $\begin{array}{l}\text { half the diagonal of the } \\
\text { drainfield }\end{array}$ \\
\hline$L_{\text {drain }}$ & {$\left[\mathrm{m}^{2}\right]$} & drainfield side length \\
\hline$L_{\mathrm{ext}}$ & {$[\mathrm{m}]$} & source area extension \\
\hline$L_{\text {lot }}$ & {$[\mathrm{m}]$} & side length of a lot \\
\hline$L_{\text {lot_red }}$ & {$[\mathrm{m}]$} & reduced side length of a lot \\
\hline$L_{\min }$ & {$[\mathrm{m}]$} & $\begin{array}{l}\text { separation distance } \\
\text { drainfield to lot boundary }\end{array}$ \\
\hline$L_{\text {red }}$ & {$[\mathrm{m}]$} & $\begin{array}{l}\text { separation distance } \\
\text { drainfield center to lot } \\
\text { boundary }\end{array}$ \\
\hline L1-L6 & {$[-]$} & $\begin{array}{l}\text { lot sizes of } 2023 ; 4047 \\
35330 ; 53000 ; 80937 \\
353300 \mathrm{~m}^{2}\end{array}$ \\
\hline$Q_{\mathrm{P}}$ & {$\left[\mathrm{m}^{3} \mathrm{yr}^{-1}\right]$} & total domestic pumpage \\
\hline$Q_{\mathrm{R}}$ & {$\left[\mathrm{m}^{3} \mathrm{yr}^{-1}\right]$} & total recharge \\
\hline$Q_{\mathrm{S}}$ & {$\left[\mathrm{m}^{3} \mathrm{yr}^{-1}\right]$} & septic drainfield recharge \\
\hline$a, b, c, d$ & {$[-]$} & regression parameters \\
\hline$i$ & {$[-]$} & running index \\
\hline$n_{\mathrm{L}}$ & {$[-]$} & number of considered lots \\
\hline$p$ & {$[-]$} & $\begin{array}{l}\text { intersection probability for } \\
\text { a given flow direction }\end{array}$ \\
\hline$p_{\mathrm{i}}$ & {$[-]$} & $\begin{array}{l}\text { intersection probability for } \\
\text { a single lot }\end{array}$ \\
\hline$p_{\mathrm{T}}$ & {$[-]$} & total intersection probability \\
\hline $\mathrm{x}, \mathrm{y}$ & {$[\mathrm{m}]$} & $\begin{array}{l}\text { directions of the spatial } \\
\text { coordinate system }\end{array}$ \\
\hline$\Phi_{\text {flow }}$ & {$\left[{ }^{\circ}\right]$} & $\begin{array}{l}\text { rotation angle (groundwater } \\
\text { flow direction/source area } \\
\text { orientation) }\end{array}$ \\
\hline
\end{tabular}


Acknowledgements. We are grateful for the careful and constructive review of this manuscript by Aaron King, University of California, Davis. This work was partially funded by State Water Resources Control Board, California, Agreement \# 04-184-555-0. Further funding was provided by the German Academic Exchange Service (DAAD).

Edited by: S. Thompson

\section{References}

Ahmed, W., Neller, R., and Katouli, M.: Evidence of septic system failure determined by a bacterial biochemical fingerprinting method, J. Appl. Microbiol., 98, 910-920, doi:10.1111/j.13652672.2004.02522.x, 2005.

Alhajjar, B., Stramer, S., Cliver, D., and Harkin, J.: Transport modelling of biological tracers from septic systems, Water Res., 22, 907-915, doi:10.1016/0043-1354(88)90028-0, 1988.

Arnade, L.: Seasonal correlation of well contamination and septic tank distance, Ground Water, 37, 920-923, doi:10.1111/j.17456584.1999.tb01191.x, 1999.

Bauman, B. and Schäfer, W.: Estimating ground-water quality impacts from on-site sewage treatment systems, in: Proceedings of the Fourth National Home Sewage Treatment Symposium, American Society of Agricultural Engineers, New Orleans, Louisiana, 285-294, 1985.

BGR: WHYMAP - World-wide Hydrogeological Mapping and Assessment Programme, http://www.whymap.org/whymap/EN/ Home/whymap_node.html, last access: 12 June 2012.

Bicki, T., Brown, R., Collins, M., Mansell, R., and Rothwell, D.: Impact of on-site sewage disposal systems on surface and ground water quality - Summary of a report to the Florida Department of Health and Rehabilitative Services, Notes in Soil Science No. 17, Soil Science Department, Institute of Food and Agricultural Sciences, University of Florida Location, Gainesville, FL, USA, 1985.

Bishop, C., Wallace, J., and Lowe, M.: Recommended septic tank soil-absorption system densities for the principal valley-fill aquifer, Sanpete Valley, Sanpete County, Utah, Report of Investigation 259, Utah Geological Survey, Salt Lake City, Utah, 2007.

Borchardt, M., Bradbury, K., Alexander Jr., E., Kolberg, R., Alexander, S., Archer, J., Braatz, L., Forest, B., Green, J., and Spencer, S.: Norovirus outbreak caused by a new septic system in a dolomite aquifer, Ground Water, 49, 85-97, doi:10.1111/j.17456584.2010.00686.x, 2011.

Brown, K. W.: An assessment of the impact of septic leachfields, home lawn fertilization, and agricultural activities on groundwater quality, Report to the new jersey pinelands commission, K. W. Drown Assoc., College Station, Texas, 1980.

Burow, K., Shelton, J., Hevesi, J., and Weissmann, G.: Hydrogeologic characterization of the Modesto area, Scientific Investigations Report 2004-5232, US Department of the Interior, US Geological Survey, Reston, Virginia, USA, 2004.

Canter, L.: Nitrates in groundwater, CRC, Chelsea, Michigan, USA, 1997.

Carrara, C., Ptacek, C., Robertson, W., Blowes, D., Moncur, M., Sverko, E., and Backus, S.: Fate of pharmaceutical and trace organic compounds in three septic system plumes, Ontario, Canada, Environ. Sci. Technol., 42, 2805-2811, doi:10.1021/es070344q, 2008.

Carroll, S., Goonetilleke, A., Thomas, E., Hargreaves, M., Frost, R., and Dawes, L.: Integrated risk framework for onsite wastewater treatment systems, Environ. Manage., 38, 286-303, doi:10.1007/s00267-005-0280-5, 2006.

Charles, K., Ashbolt, N., Roser, D., McGuinness, R., and Deere, D.: Effluent quality from 200 on-site sewage systems: design values for guidelines, Water Sci. Technol., 51, 163-169, 2005.

Corbett, R., Dillon, K., Burnett, W., and Schaefer, G.: The spatial variability of nitrogen and phosphorus concentration in a sand aquifer influenced by onsite sewage treatment and disposal systems: a case study on St. George Island, Florida, Environ. Pollut., 117, 337-345, doi:10.1016/S0269-7491(01)00168-3, 2002.

Dawes, L. and Goonetilleke, A.: An investigation into the role of site and soil characteristics in onsite sewage treatment, Environ. Geol., 44, 467-477, doi:10.1007/s00254-003-0781-6, 2003.

DeBorde, D., Woessner, W., Lauerman, B., and Ball, P.: Virus occurrence and transport in a school septic system and unconfined aquifer, Ground Water, 36, 825-834, doi:10.1111/j.17456584.1998.tb02201.x, 1998.

DeSimone, L.: Quality of Water from Domestic Wells in Principal Aquifers of the United States, 1991-2004, Scientific Investigations Report 2008-5227, US Geological Survey, Reston, Virginia, USA, 2009.

Drake, V. and Bauder, J.: Ground water nitrate-nitrogen trends in relation to urban development, Helena, Montana, 1971-2003, Ground Water Monitor. Remed., 25, 118-130, doi:10.1111/j.1745-6592.2005.0017.x, 2005.

Dubrovsky, N., Burow, K., Clark, G., Gronberg, J., Hamilton, P., Hitt, K., Mueller, D., Munn, M., Nolan, B., Puckett, L., Rupert, M., Short, T., Spahr, N., Sprague, L., and Wilber, W.: Nutrients in the Nation's Streams and Groundwater, 1992-2004, Circular 1350, US Geological Survey, Reston, VA, USA, 2010.

Duda, A. and Cromartie, K.: Coastal pollution from septic tank drainfields, J. Environ. Eng. Div., 108, 1265-1279, 1982.

Fong, T., Mansfield, L., Wilson, D., Schwab, D., Molloy, S., and Rose, J.: Massive microbiological groundwater contamination associated with a waterborne outbreak in Lake Erie, South Bass Island, Ohio, Environ. Health Persp., 115, 856-864, doi:10.1289/ehp.9430, 2007.

Frazier, C., Graham, R., Shouse, P., Yates, M., and Anderson, M.: A field study of water flow and virus transport in weathered granitic bedrock, Vadose Zone J., 1, 113-124, doi:10.2113/1.1.113, 2002.

Gerba, C.: Applied and theoretical aspects of virus adsorption to surfaces, Adv. Appl. Microbiol., 30, 133-168, doi:10.1016/S0065-2164(08)70054-6, 1984.

Gerba, C. and James, E.: Sources of pathogenic microorganisms and their fate during land application of wastes, J. Environ. Qual., 34, 42-48, 2005.

Godfrey, E., Woessner, W., and Benotti, M.: Pharmaceuticals in On-Site Sewage Effluent and Ground Water, Western Montana, Ground Water, 45, 263-271, doi:10.1111/j.17456584.2006.00288.x, 2007.

Gray, N.: Drinking Water Quality: Problems and Solutions, Cambridge University Press, Cambridge, UK, 2008.

Hantzsche, N. and Finnemore, E.: Predicting Ground-Water Nitrate-Nitrogen Impacts, Ground Water, 30, 490-499, doi:10.1111/j.1745-6584.1992.tb01524.x, 1992. 
Harden, H., Roeder, E., Hooks, M., and Chanton, J.: Evaluation of onsite sewage treatment and disposal systems in shallow karst terrain, Water Res., 42, 2585-2597, doi:10.1016/j.watres.2008.01.008, 2008.

Harmsen, E., Converse, J., and Anderson, M.: Application of the Monte Carlo simulation procedure to estimate water-supply well/septic tank-drainfield separation distances in the Central Wisconsin sand plain, $\mathrm{J}_{\mathfrak{i}}$ Contam. Hydrol., 8, 91-109, doi:10.1016/0169-7722(91)90010-X, 1991a.

Harmsen, E., Converse, J., Anderson, M., and Hoopes, J.: A model for evaluating the three-dimensional groundwater dividing pathline between a contaminant source and a partially penetrating water-supply well, J. Contam. Hydrol., 8, 71-90, doi:10.1016/0169-7722(91)90009-P, 1991b.

Harter, T., Lund, J., Darby, J., Fogg, G., Howitt, R., Jessoe, K., Pettygrove, G., Quinn, J., Viers, J., Boyle, D., Canada, H., De LaMora, N., Dzurella, K., Fryjoff-Hung, A., Hollander, A., Honeycutt, K., Jenkins, M., Jensen, V. B., King, A., Kourakos, G., Liptzin, D., Lopez, E., Mayzelle, M., McNally, A., MedellinAzuara, J., and Rosenstock, T.: Addressing Nitrate in California's Drinking Water with a Focus on Tulare Lake Basin and Salinas Valley Groundwater, Report for the State Water Resources Control Board Report to the Legislature, http://groundwaternitrate. ucdavis.edu, last access: 12 June 2012.

Heberer, T.: Tracking persistent pharmaceutical residues from municipal sewage to drinking water, J. Hydrol., 266, 175-189, doi:10.1016/S0022-1694(02)00165-8, 2002.

Horn, J. and Harter, T.: Domestic well capture zone and influence of the gravel pack length, Ground Water, 47, 277-286, doi:10.1111/j.1745-6584.2008.00521.x, 2009.

Humphrey Jr., C., O'Driscoll, M., and Zarate, M.: Controls on groundwater nitrogen contributions from on-site wastewater systems in coastal North Carolina, Water Sci. Technol., 62, 1448, doi:10.2166/wst.2010.417, 2010.

Kaplan, O.: Septic Systems Handbook, Lewis Publishers, Chelsea, Michigan, USA, 1991.

Katz, B., Lindner, J., and Ragone, S.: A Comparison of Nitrogen in Shallow Ground Water from Sewered and Unsewered Areas, Nassau County, New York, from 1952 through 1976a, Ground Water, 18, 607-616, doi:10.1111/j.1745-6584.1980.tb03655.x, 1980.

Katz, B., Eberts, S., and Kauffman, L.: Using $\mathrm{Cl} / \mathrm{Br}$ ratios and other indicators to assess potential impacts on groundwater quality from septic systems: A review and examples from principal aquifers in the United States, J. Hydrol., 397, 151-166, doi:10.1016/j.jhydrol.2010.11.017, 2011.

Kerfoot, W.: Is private well protection adequate when ground water flow is ignored, in: Focus on Eastern Ground Water Issues, National Water Well Association, Burlington, Vermont, 1987.

Konikow, L., Bredehoeft, J., and of the Interior, U. S. D.: Computer model of two-dimensional solute transport and dispersion in ground water, US Govt. Print. Off., Reston, Virginia, 1978.

Kunstmann, H. and Kastens, M.: Determination of stochastic well head protection zones by direct propagation of uncertainties of particle tracks, J. Hydrol., 323, 215-229, doi:10.1016/j.jhydrol.2005.09.003, 2006.

Lipp, E., Farrah, S., and Rose, J.: Assessment and impact of microbial fecal pollution and human enteric pathogens in a coastal community, Mar. Pollut. Bull., 42, 286-293, doi:10.1016/S0025-
326X(00)00152-1, 2001.

Lowe, M., Wallace, J., and Bishop, C.: Ground-water quality classification and recommended septic tank soil-absorptionsystem density maps, Cache Valley, Cache County, Utah, Special Study 101, Utah Geological Survey, Salt Lake City, Utah, 2003.

Lowe, M., Sabbah, W., and Wallace, J.: Ground-water model based septic-tank density recommendations using a mass balance approach to protect ground-water quality, Cedar Valley, Iron County, Utah, in: Rocky Mountain (63rd Annual) and Cordilleran (107th Annual) Joint Meeting (18-20 May 2011), vol. 43, Geological Society of America, Boulder, CO, USA, p. 74, 2011.

Miller, J.: Nitrate contamination of the water-table aquifer in Delaware, Report of Investigation 20, Delaware Geological Survey, Newark, DE, USA, , 1972.

Miller, L. and Ortiz, R.: Ground-Water Quality and Potential Effects of Individual Sewage Disposal System Effluent on Ground-Water Quality in Park County, Colorado, 2001-2004, Scientific Investigations Report 2007-5220, US Geological Survey, Reston, VA, USA, 2007.

Musolff, A.: Micropollutants: challenges in hydrogeology, Hydrogeol. J., 17, 763-766, doi:10.1007/s10040-009-0438-y, 2009.

Nicosia, L., Rose, J., Stark, L., and Stewart, M.: A field study of virus removal in septic tank drainfields, J. Environ. Qual., 30, 1933, doi:10.2134/jeq2001.1933, 2001.

Nizeyimana, E., Petersen, G., Anderson, M., Evans, B., Hamlett, J., and Baumer, G.: Statewide GIS/census data assessment of nitrogen loadings from septic systems in Pennsylvania, J. Environ. Qual., 25, 346-354, doi:10.2134/jeq1996.00472425002500020020x, 1996.

Osenbrück, K., Gläser, H., Knöller, K., Weise, S., Möder, M., Wennrich, R., Schirmer, M., Reinstorf, F., Busch, W., and Strauch, G.: Sources and transport of selected organic micropollutants in urban groundwater underlying the city of Halle (Saale), Germany, Water Res., 41, 3259-3270, doi:10.1016/j.watres.2007.05.014, 2007.

Pang, L., Nokes, C., Simunek, J., Kikkert, H., and Hector, R.: Modeling the impact of clustered septic tank systems on groundwater quality, Vadose Zone J., 5, 599-609, doi:10.2136/vzj2005.0108, 2006.

Perkins, R.: Septic tanks, lot size and pollution of water table aquifers, J. Environ. Health, 46, 298-304, 1984.

Pitt, W.: Effects of septic tank effluent on groundwater quality, Dade County, Florida - An interim report, Open-File Report 74-010, US Geological Survey, Reston, Virginia, USA, 1974.

Pitt, W.: Effects of septic tank effluent on groundwater quality, Dade County, Florida, Open-File Report 75-607, US Geological Survey, Reston, Virginia, USA, 1975.

Postma, F., Gold, A., and Loomis, G.: Nutrient and microbial movement from seasonally-used septic systems, J. Environ. Health, 55, 5-10, 1992.

Robertson, W. and Cherry, J.: Hydrogeology of an unconfined sand aquifer and its effect on the behavior of nitrogen from a large-flux septic system, Hydrogeol. J., 0, 32-44, doi:10.1007/PL00010960, 1992.

Robertson, W., Cherry, J., and Sudicky, E.: Ground-Water Contamination from Two Small Septic Systems on Sand Aquifers, Ground Water, 29, 82-92, doi:10.1111/j.17456584.1991.tb00500.x, 1991. 
Rudel, R., Melly, S., Geno, P., Sun, G., and Brody, J.: Identification of alkylphenols and other estrogenic phenolic compounds in wastewater, septage, and groundwater on Cape Cod, Massachusetts, Environ. Sci. Technol., 32, 861-869, doi:10.1021/es970723r, 1998.

Scandura, J. and Sobsey, M.: Viral and bacterial contamination of groundwater from on-site sewage treatment systems, Water Sci. Technol., 35, 141-146, doi:10.1016/S0273-1223(97)002497, 1997.

Schmidt, K.: Nitrate in Ground Water of the Fresno-Clovis Metropolitan Area, Californiaa, Ground Water, 10, 50-64, doi:10.1111/j.1745-6584.1972.tb02900.x, 1972.

Standley, L., Rudel, R., Swartz, C., Attfield, K., Christian, J., Erickson, M., and Brody, J.: Wastewater-contaminated groundwater as a source of endogenous hormones and pharmaceuticals to surface water ecosystems, Environ. Toxicol. Chem., 27, 2457-2468, doi:10.1897/07-604.1, 2008.

Stanford, B., Amoozegar, A., and Weinberg, H.: The impact of co-contaminants and septic system effluent quality on the transport of estrogens and nonylphenols through soil, Water Res., 44, 1598-1606, doi:10.1016/j.watres.2009.11.011, 2010.

Swartz, C., Reddy, S., Benotti, M., Yin, H., Barber, L., Brownawell, B., and Rudel, R.: Steroid estrogens, nonylphenol ethoxylate metabolites, and other wastewater contaminants in groundwater affected by a residential septic system on Cape Cod, MA, Environ. Sci. Technol., 40, 4894-4902, doi:10.1021/es052595+, 2006.

SWRCB: Onsite wastewater treatment system policy - Draft substitute environmental document, http://www.waterboards.ca. gov/water_issues/programs/owts/docs/draft_final_sed2012.pdf, last access: 12 June 2012.

Trela, J. and Douglas, L.: Soils septic systems and cyrrying capacity in the pine barrens, in: Proc. and Papers of First Res. Conf., N.J., Pine Barrens, 37-58, 1978.

US DC: American Housing Survey for the United States: 2007, H150/07, http://www.census.gov/prod/2008pubs/h150-07. pdf (last access: 12 June 2012), 2008.

US EPA: The Report to Congress: Waste Disposal Practices and Their Effects on Groundwater, EPA 570/9-77-002, US Environmental Protection Agency (EPA), Washington, D.C., USA, 1977.

US EPA: National Water Quality Inventory: 1996 Report to Congress. EPA 841-R-97-008, http://water.epa.gov/lawsregs/ guidance/cwa/305b/96report_index.cfm, 1998.

US EPA: National Water Quality Inventory: National Water Quality Inventory: 2000 Report, EPA-841-R-02-001, http://water.epa.gov/lawsregs/guidance/cwa/305b/upload/ 2009_01_22_305b_2004report_2004_305Breport.pdf, 2002a.

US EPA: Onsite Wastewater Treatment Systems Manual, EPA/625/R-00/008, http://cfpub.epa.gov/owm/septic/septic. cfm?page_id=268, 2002b.
US EPA: Drinking Water From Household Wells, EPA 816K-02-003, http://water.epa.gov/drink/info/well/upload/2003_06_ 03_privatewells_pdfs_household_wells.pdf, 2002c.

US EPA: Voluntary national guidelines for management of onsite and clustered (decentralized) wastewater treatment systems, EPA 832-B-03-001, http://www.epa.gov/owm/septic/pubs/ septic_guidelines.pdf, 2003a.

US EPA: National primary drinking water standards, EPA 816F-03-016, http://www.epa.gov/ogwdw/consumer/pdf/mcl.pdf, 2003 b.

US EPA: Decentralized Wastewater Treatment Systems: A Program Strategy, EPA 832-R-05-002, http://www.epa.gov/owm/septic/ pubs/septic_program_strategy.pdf, 2005.

Verstraeten, I., Fetterman, G., Meyer, M., Bullen, T., and Sebree, S.: Use of tracers and isotopes to evaluate vulnerability of water in domestic wells to septic waste, Ground Water Monitor. Remed., 25, 107-117, doi:10.1111/j.1745-6592.2005.0015.x, 2005.

Whitehead, J. and Geary, P.: Geotechnical aspects of domestic onsite effluent management systems, Aust. J. Earth Sci., 47, 75-82, doi:10.1046/j.1440-0952.2000.00769.x, 2000.

Wilcox, J., Gotkowitz, M., Bradbury, K., and Bahr, J.: Using Groundwater Models to Evaluate Strategies for Drinking-Water Protection in Rural Subdivisions, J. Am. Plan. Assoc., 76, 295304, doi:10.1080/01944361003742403, 2010.

Woodson, R. D.: Water wells and septic systems handbook, Irwin/McGraw Hill,, New York, NY, USA, 2003.

Worboys, M. and Duckham, M.: GIS: A computing perspective, 2nd Edn., CRC Press, Boca Raton, USA, 2004.

Wright, J.: Water quality and solid waste problems in rural new mexico and some solutions, in: Water pollution control in low density areas, edited by: Jewell, W. and Swan, R., University Press of New England, Hanover, New Hampshire, 1975.

Yates, M.: Septic Tank Density and Ground-Water Contamination, Ground Water, 23, 586-591, doi:10.1111/j.17456584.1985.tb01506.x, 1985.

Yates, M.: Microorganisms: The drinking water contaminats of the '90's?, Cooperative Extension University of California Environmental Toxicology Newsletter 11(1), University of California, 1991.

Yates, M. and Yates, S.: Septic Tank Setback Distances: A Way to Minimize Virus Contamination of Drinking Watera, Ground Water, 27, 202-208, doi:10.1111/j.1745-6584.1989.tb00441.x, 1989.

Yates, M., Gerba, C., and Kelley, L.: Virus persistence in groundwater, Appl. Environ. Microbiol., 49, 778-781, 1985. 